Archived version from NCDOCKS Institutional Repository http://libres.uncg.edu/ir/asu/

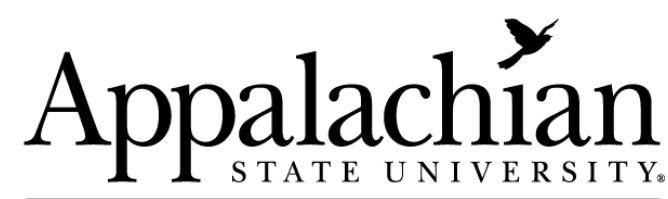

B O O N E, NORT H C A R O L I A

\section{Using A Community Tourism Development Model To Explore Equestrian Trail Tourism Potential In Virginia}

\author{
By: Carol S. Kline, David Cardenas, Paige P. Viren, \& Jason R. Swanson
}

\begin{abstract}
As the tourism industry grows so does the demand by tourists for specialized travel alternatives. One niche market that is growing but has received very little attention in the tourism literature is equestrian tourism. Increased demand makes the development and planning of equestrian tourism critical to minimize conflict among stakeholders, and provide necessary infrastructure for patrons. The purpose of this study was to assess equestrian trail riders' perceptions and attitudes about the viability of and need for equestrian trail tourism development in their community. An online survey was conducted with members of the Virginia Horse Council. According to the findings, not only was equestrian trail tourism viewed as a viable industry for the county, current resource users voiced their support for expanding the market, which would result in retention and growth among related businesses and facilities. Trail riders felt that the greatest needs in developing equestrian tourism lay in the areas of marketing, support from officials, educating local officials about the economic importance of the horse industry, organization within the horse community, and developing additional trails. Results from this study will be useful in a general sense for rural tourism planners within and outside of the community wishing to increase equestrian trail tourism.
\end{abstract}

Kline, C. S., et al. (2015). "Using a community tourism development model to explore equestrian trail tourism potential in Virginia." Journal of Destination Marketing \& Management 4(2): 79-87. https://doi.org/10.1016/ j.jdmm.2015.01.001. Publisher version of record available at: https://www.sciencedirect.com/science/article/pii/ S2212571X15000025 


\title{
Using a community tourism development model to explore equestrian trail tourism potential in Virginia
}

\author{
Carol S. Kline ${ }^{a, n}$, David Cardenas ${ }^{b}$, Paige P. Viren ${ }^{c}$, Jason R. Swanson ${ }^{\mathrm{d}}$ \\ ${ }^{a}$ Hospitality and Tourism Management, Walker College of Business, Appalachian State University, 4078 Peacock Hall, Boone, NC 28608, USA \\ b School of Hotel, Restaurant, and Tourism Management, Center of Economic Excellence (CoEE) and Tourism and Economic Development, \\ Coliseum Room 1011, Columbia, SC 29208, USA \\ ${ }^{c}$ Recreation and Leisure Studies, Center for Sustainable Tourism, East Carolina University, Belk Building 1408, Greenville, NC 27858, USA \\ ${ }^{\mathrm{d}}$ Retailing and Tourism Management, College of Agriculture, Food and Environment, University of Kentucky, 120 Erikson Hall, Lexington, KY 40506, USA
}

a r t ic le i n fo

Keywords:

Equestrian trail tourism

Trail development

Horseback riding

Community development model a b s t r a c t

As the tourism industry grows so does the demand by tourists for specialized travel alternatives. One niche market that is growing but has received very little attention in the tourism literature is equestrian tourism. Increased demand makes the development and planning of equestrian tourism critical to minimize conflict among stakeholders, and provide necessary infrastructure for patrons. The purpose of this study was to assess equestrian trail riders' perceptions and attitudes about the viability of and need for equestrian trail tourism development in their community. An online survey was conducted with members of the Virginia Horse Council. According to the findings, not only was equestrian trail tourism viewed as a viable industry for the county, current resource users voiced their support for expanding the market, which would result in retention and growth among related businesses and facilities. Trail riders felt that the greatest needs in developing equestrian tourism lay in the areas of marketing, support from officials, educating local officials about the economic importance of the horse industry, organization within the horse community, and developing additional trails. Results from this study will be useful in a general sense for rural tourism planners within and outside of the community wishing to increase equestrian trail tourism.
1. Equestrian trail tourism: trail riders perspective on blazing new trails in Virginia

Outdoor recreation activities such as hiking, walking, paddling, bird watching and horseback riding are key travel motivators, occur in a variety of settings, are intricately linked to the tourism development process, and are often developed by entrepreneurs within the community. However, existing models of community-based tourism development and other relevant literature often do not consider the unique attributes of outdoor recreation activities that are studied far less than others - for example, equestrian trail tourism (ETT).

Two of the most popular forms of outdoor recreation activities are walking and hiking (Oh \& Hammitt, 2010) and both have received extensive attention in the tourism literature (Kyle, Graefe, \& Manning, 2004; Marion \& Leung, 2001). Comparatively little has been written about equestrian tourism or horse tourism (Newsome, Smith, \& Moore, 2008). Much of the limited research that has been conducted has concentrated on the negative environmental impacts that horses

\footnotetext{
${ }^{\mathrm{n}}$ Corresponding author. Tel.: p1 919306 1705; fax: p1 9197879830.

E-mail addresses: klinec@me.com,klinecs@appstate.edu (C.S. Kline), dcardenas@hrsm.sc.edu (D. Cardenas).
}

create on trails such as degradation of existing trails (Deluca, Patterson, Freimund, \& Cole, 1998; Törn, Tolvanen, Norokorpi, Tervo, \& Siikamäki, 2009), loss of flora and fauna (Phillips \& Newsome, 2002) and introduction of foreign material (Marion, Cole, \& Bratton, 1986). Management strategies have been developed to help minimize many of these impacts, including zoning, trail reconstruction, and altering visitor behavior (Landsberg, Logan, \& Shorthouse, 2001; Newsome, Milewski, Phillips, \& Annear, 2002; Royce, 1983), but little attention has been given to appropriate planning and development strategies for ETT.

A few studies written about the social impacts of horse riding have focused on user conflict in multiple use areas (Newsome et al., 2002) or crisis management (Beeton, 2001). A study conducted by Watson, Niccolucci, and Williams (1994) in the John Muir Wilderness Area found that $44 \%$ of hikers disliked encounters with horseback riders, while only $4 \%$ of horseback riders disliked their encounter with hikers. Hikers indicated that they disliked the manure on the trails, noise from the group, and rudeness of the horseback riders. Beeton's (1999a, 1999b) study mirrored those sentiments. Conducted in Australia, her work assessed the different attitudes between bushwalkers (hikers) and horseback riders. Results indicated that there was a very strong dislike for the horseback riding groups. Bushwalkers perceived the groups as environmentally disrespectful and the majority (54\%) went so far as to move camp if horse riding groups were present. Echoing 
this finding is a National Park Service study conducted by Marion, Roggenbuck, and Manning (1993). They reported that conflicts between horseback riders and hikers were a problem in $9 \%$ of the participating U.S. parks. Mulders (2006) conducted one of the most recent studies to assess riders' perceptions of the environmental impacts created by riding. Results indicated that riders felt they created minimal environmental impacts, especially if they stay on trails. One of the key findings was the need for additional trail development. It was pointed out that lack of management and limited tracks and trails could result in injury not only to horses, but to riders and other users as well, which agrees with more recent studies of Beeton (2001) and Räbinä (2010).

As illustrated above, most research is outdated with limited implications on the sustainable tourism planning and development process. Yet, the horse industry is growing and represents a large segment of the travel market with significant economic impact on local communities (Daniels \& Norman, 2005; Hackbert \& Lin, 2009; Helgadóttir, 2006; Helgadottir \& Sigurdardottir, 2008; Ollenburg, 2005; Räbinä, 2010). The American Horse Council (AHC) reported that there are over 2 million horse owners and 9.2 million horses in the United States. Overall the industry has an economic impact (direct and indirect) in the US of $\$ 101$ billion and employees over 1.4 million people. The AHC (n.d.) states that recreation accounts for almost one-third of the economic impact ( $\$ 32$ billion) and employees (435,082 people). In North Carolina alone the total economic impact is $\$ 1.9$ billion and supports over 19,000 jobs (N.C. Center for Rural Economic Development, 2009). In what can be considered more horse-centric states, the economic effects of the equine industry are much higher, as is the case in Kentucky - home to over 242,000 horses. Kentucky's equine industry has been estimated at $\$ 23.4$ billion (Blood-Horse Magazine, 2013). It is anticipated that economic impact numbers will increase both in the United States and around the world as indicated by the steady growth of membership numbers in equestrian horse clubs (Helgadottir \& Sigurdardottir, 2008).

There is a dearth of research specific to equestrian tourism trail development, however a great deal has been written about greenway and trail development for other outdoor recreation activities. Data and recommendations from previous studies provide useful information and insight into new infrastructure options (Boers \& Cottrell, 2007), attitudes and perceptions of stakeholders (Kline, Cardenas, Duffy, \& Swanson, 2012), targeted marketing techniques (Biches-Lupas \& Moisey, 2001) and evaluation methods (Newsome \& Davies, 2009). An example of previous research includes a study by Ivy and Moore (2007) and focused on the differences between adjacent and nearby property owners' attitudes toward proposed trail development near their neighborhood. Overall they found that both groups were supportive of the development; however adjacent landowners were less supportive because of concerns of potential property value decreasing. They recommend that development projects should include education as a core requirement for all stakeholders. In addition, Kline et al. (2012) conducted a study to examine the different funding options that may assist in the development and maintenance of paddle trails. Results indicated that females and recreational paddlers were more likely to support funding mechanisms; in addition, willingness-to-pay increased in participants who perceived trails as an economic generation tool. A 2001 special edition of Journal of Parks and Recreation Administration that focused specifically on trails and greenways highlighted the need for more research on planning and development (Moore \& Shafer, 2001).

In light of the growth of equestrian tourism, it is critical that research is conducted to determine how to properly plan and help ensure this product is a sustainable option for the local community. One critical tenant of sustainability is the concept of stakeholder involvement and education (Byrd, Cardenas, \& Greenwood, 2008). Stakeholders can be defined as, "any group or individual who can affect or is affected by the achievement of the organizations objectives" (Freeman, 1984, p. 46). Stakeholder theory is entrenched in the business and management literature, with the basic premise that if there is interest in the product or organization, they should have the right to be involved (Donaldson \& Preston, 1995). In the realm of tourism, stakeholders are classified as tourists, business owners or entrepreneurs, government officials, and the local community (Goeldner \& Ritchie, 2012). Studies show that when stakeholders collaborate and participate in the planning and development process it assists in minimizing

Community Tourism Development Planning Model

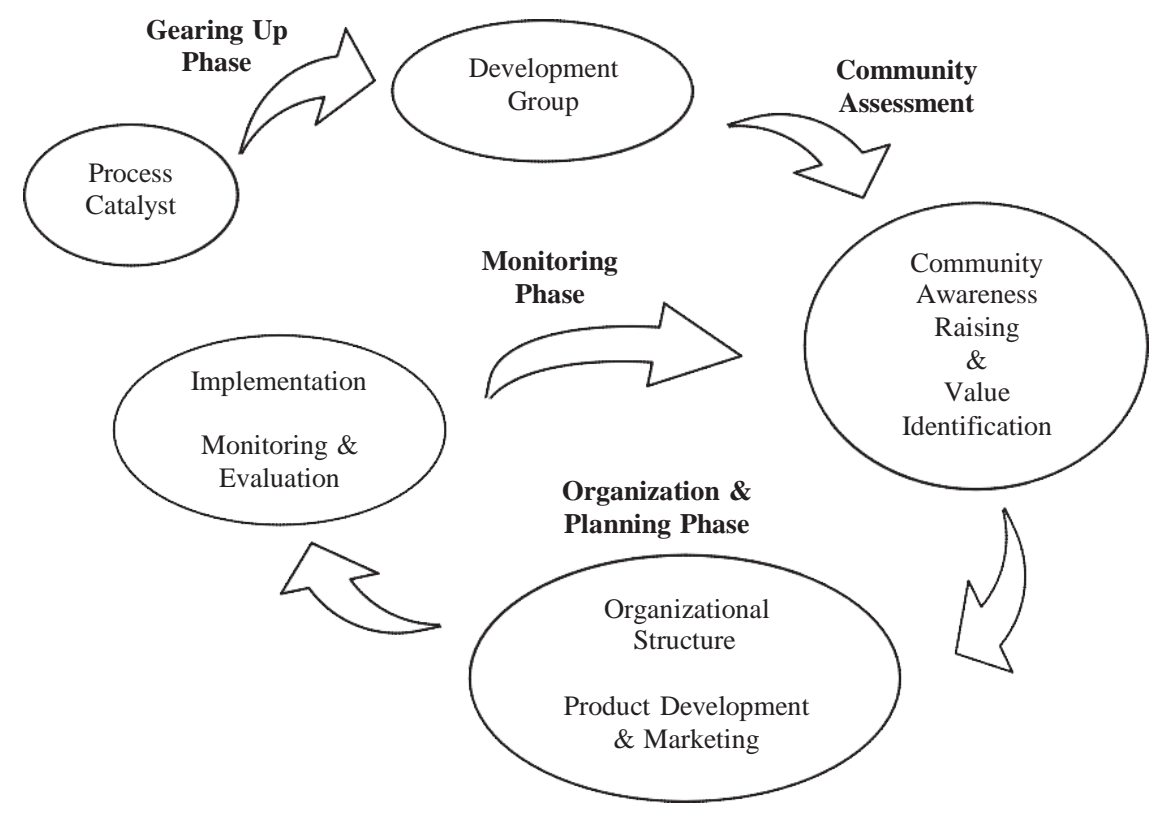

Adapted from Reid, Fuller, Haywood \& Bryden (1993). 
negative impacts such as conflict, while also enhancing the positive impacts tourism creates such jobs and increased market share (Byrd, 2007). Collaborating and working together to solve problems is a key component in sustainability and in today's competitive tourism industry. Gray (1989) defines collaboration as, "a process of joint decision-making among key stakeholders of a problem domain about the future of that domain" (p. 11). When conflict occurs, collaboration can be used to solve the conflict, and particularly when stakeholders understand the rewards of teamwork (Jamal \& Getz, 1995). By collaborating at the local tourism level, planning and development issues are processed with a more vibrant approach. An initial step in the collaboration process is by assessing the stakeholders' perceptions and attitudes (Byrd, 2007).

Reid, Fuller, Haywood, and Bryden (1993) put forth a model for community-based tourism development that incorporates many stages for stakeholder involvement: community participation, identifying community values, marketing and product development, and plan implementation, all of which have been found by other studies in this literature review to be critical components of tourism development (Fig. 1). Reid, Mair, and Taylor (2000) later expanded the model by focusing on raising community awareness and by showing that tensions can build between community members and tourism developers if there is a lack of community involvement. Following that, Reid, Mair, and George (2004) operationalized the community involvement and awareness components of the model and devised tactics to enhance community involvement.

This study uses the Reid et al. (1993) Community-based Tourism Development model as the basis for analysis of the findings and expands the model to include elements unique to the development of ETT. The first three components of the model easily characterize this research. The catalyst process is the rise in demand for specialized travel alternatives, particularly the burgeoning interest in ETT in Virginia. In this case, the development group is the Virginia Horse Council and the survey research is an effort to assess the community. Continuing the development of the organization and planning aspects of the model, this study focused on one key community stakeholder group - horseback riders who live within the proposed equestrian trail development region. The purpose was to gather critical information about riders and their perception of the viability of community-based tourism development. The research questions are

1. What do trail riders consider necessary for ETT development in their community?

2. Do riders living in communities with more local trail assets and infrastructure (in their county) consider tourism development more feasible than those who do not?

3. Are there differences in perceptions about ETT development among different types of members of the trail rider community?

\section{Methods}

As part of a larger study, this project was designed for the Virginia Horse Council (VHC). The council is a non-profit organization in existence to expand the equine industry whose members include adult and youth horsemen, breed groups, related industries, shows, farms, sales, clubs, schools, stables and pleasure horse owners. The VHC "serves all the horseman and women of Virginia [and] advocates for all regardless of whether or not they support our efforts financially through membership" (Sally Augnier, personal communication). The survey was conducted to obtain the information regarding the opinions of horseback trail riders in the state. The initial survey design involved collaboration with one of the authors and Sally Augnier, staff member of the Horse Council. The questions targeted rider preferences and travel patterns, desired trail/camping amenities, expenditures while traveling, as well as future trail development potential and issues. Question format included multiple choice, matrix choice, rating scale, and openended text options. Some of the general questions on travel patterns were adapted from previous visitors studies, and a set of questions focusing on available tourism and equine-related assets was adapted from the technical report Developing Equine Tourism Opportunities in North Carolina: An Online Survey of County Needs (Kline, Potter, \& Mowrey, 2006). Many questions relating to trail infrastructure and development were developed by the Horse Council staff member based on knowledge of lodging, amenity, and infrastructure needs of trail riders. Additional input was gained during a focus group of equestrian enthusiasts, resource managers, and service providers held at the Virginia Parks and Recreation Annual Conference in the summer of 2008; modifications were made to the survey instrument based on feedback.

Developed from the aforementioned research, a fifty-question on-line survey was developed and solicitation for participation was conducted through the Virginia Horse Council member database, an equestrian-related listserv, and memberships to local equestrian and riding clubs within the state. Recipients of the online survey solicitation were encouraged to pass along the survey link to other interested parties therefore a snowball sampling technique was used. The survey was available for a period of three weeks in September of 2008. Qualitative data was coded separately by three researchers to ensure inter-coder reliability. Quantitative analysis was conducted in SPSS 19.0.

\section{Results}

\subsection{Rider profile}

At the close of the survey, 653 usable surveys were recorded. The majority of respondents were female $(88.1 \%)$ and between the ages of 41-60 years old (72.2\%). Over two-fifths (43.1\%) were self-employed or employed in the private sector, while almost a third (30.5\%) work in the public sector. Household income was fairly evenly distributed within the $\$ 25,000$ to over $\$ 200,000$ range, with $39.7 \%$ in the income category of $\$ 50,000-\$ 99,000$. Respondents represented a cross section of the state from nearly every county in the state. The demographic structure of the respondents of this study is similar to previous studies equestrian studies with respect to age and household income (American Horse Council, n.d.). Just over half of respondents (55.1\%) described themselves as "avid" trail riders, with almost one third (31.1\%) describing themselves as an "occasional" trail rider (Table 1). Respondents were asked to check as many riding companions that apply. Most of the respondents (90.0\%) typically ride with friends, while over half $(54.4 \%)$ ride by themselves and another $40 \%(40.6 \%)$ ride with a club. Riding with one's spouse $(27.9 \%)$ and one's family $(27.6 \%)$ is also popular ( $\left.n^{1 / 4} 818\right)$. Most respondents $(64.8 \%)$ take daytrips for riding, and forested trails $(92.3 \%)$ were by far the most popular.

\subsection{Prevalence of ETT and ETT assets}

Respondents were asked if they thought trail-riding tourism could be a viable industry for their county, with response options ranging from 1 to 10, where 1 represented "not viable at all," and 10 represented "very viable." Of the 637 respondents, $15.7 \%$ indicated a low level of viability (1-3), $24.3 \%$ a moderate viability (4-6), and $60.1 \%$ a high degree of viability (7-10). When respondents were asked if they currently had trail riding tourists coming to the county, 13.8\% said "a great deal," 39.5\% responded "some," another 13.8\% stated that they did not, and a third $33.0 \%$ were unsure $\left(n^{1 / 4} 646\right)$. Respondents were also asked to note the presence of various tourism-related assets and various equine-related assets within their county (Tables 2 and 3). The items were adapted from similar categorization used by Kline et al. 
(2006). While the list of Tourism-related Assets are geared towards the traveler with equestrian interests, the items in the Equine-related Assets list are resources used primarily by the community; some of the items in each list would easily fit into both classifications (e.g. vet, boarding facilities, fairgrounds, parks, and horseback search and rescue).

Within the list of tourism-related assets, a tack/fee shop (82.4\%), equine practitioner/vet (81.4\%), and boarding facilities (79.0\%) are the most prevalent in the respondents' counties. Following these, riding trails $(72.9 \%)$, a facility for small-moderate equestrian events $(68.9 \%)$, and riding lessons $(58.7 \%)$ is available in more than half of the respondents' counties. The presence of tourism-related assets dropped considerably after this to include large equestrian event facilities (28.9\%), lodging/boarding combination facilities $(23.0 \%)$, and horses that can be rented by visitors $(20.6 \%)$.

Within the equine-related asset list, the most common items cited by respondents are farrier service which are present in $89.2 \%$ of respondents' home counties, followed by equine $4-\mathrm{H}$ or pony clubs

Table 1

Rider profile of participants.

\begin{tabular}{|c|c|}
\hline Profile characteristics & $\%$ \\
\hline \multicolumn{2}{|c|}{ Self-classification of rider $\left(N^{1 / 4} 650\right)$} \\
\hline Competitive trail rider & 10.0 \\
\hline Avid trail rider & 55.1 \\
\hline Occasional trail rider & 31.1 \\
\hline Novice trail rider & 3.8 \\
\hline \multicolumn{2}{|c|}{ Riding group composition ( $N 1 / 4653)$} \\
\hline tviy irıenus & yu.u \\
\hline Myself & 54.4 \\
\hline A riding club & 40.6 \\
\hline My spouse & 27.9 \\
\hline My family & 27.6 \\
\hline Fellow competitors & 11.5 \\
\hline Business colleagues & 4.1 \\
\hline My grandchildren & 3.8 \\
\hline An outfitter/guide & 1.5 \\
\hline Other organized groups & 12.9 \\
\hline \multicolumn{2}{|l|}{ Length of riding trip $\left(N^{1 / 4} 645\right)$} \\
\hline Less than full day & 64.8 \\
\hline $1-2$ days & 17.8 \\
\hline $3-4$ days & 14.9 \\
\hline 5-7 days & 1.7 \\
\hline More than 7 days & .8 \\
\hline \multicolumn{2}{|l|}{ Type of trails preference $\left(N^{1 / 4653)}\right.$} \\
\hline Forested trails & 92.3 \\
\hline Loop trails & 77.9 \\
\hline Historic trails & 69.5 \\
\hline Public trails & 60.9 \\
\hline High country mountain trails & 57.7 \\
\hline Private trails & 56.4 \\
\hline Open-area trails & 55.9 \\
\hline Linear trails & 20.1 \\
\hline
\end{tabular}

(77.3\%), livestock or 4-H shows (77.2\%), organized trail riding groups or saddle clubs $(69.3 \%)$, parks that allow riding $(67.7 \%)$, facility that have hunter-jumper competitions (56.4\%), and fairgrounds $(55.9 \%)$ (Table 3). In addition, respondents were asked to estimate the miles of trails in their county. Roughly one half of respondents (49.6\%) had less than 50 miles of trails to access, another $18 \%$ had between 50 and 100 miles, and another third (32.5\%) had over 100 miles of trails in their county.

Respondents were probed regarding the process of equestrian tourism development. Each question was framed so that it focused on equestrian tourism or trail development tourism, rather than equestrian activities, equestrian facilities, trail development or other general phrases on trail activity that might be perceived to target solely the community. Below are the thoughts from respondents on what is needed to develop ETT, as well as the results from the analysis of this information.

\subsection{Necessary elements for ETT development}

Questions regarding ETT development were framed in both positive form, e.g. What do you see as the next steps for developing trail tourism? and negative form, e.g. What are the barriers to developing trail tourism? Definite patterns emerge among existing trail riders.

To address the first research question, What do trail riders consider necessary for trail tourism development, an analysis of three openended questions and one ranking question was performed. Responses were coded using content analysis. The key themes for each of the open-ended questions are listed in Table 4.

- What kinds of training or technical assistance are needed to further equestrian tourism in your county?

- What do you see as the "next steps" in developing equestrian tourism in your county?

- What could be done to improve a visitor's equestrian experience in Virginia?

- What barriers do you see to developing this industry in your county?

The most common responses across the three questions involved marketing/advertisement, support from officials, educating local officials about the importance and economic impact of the horse industry, organization within the horse community, and need of additional places to ride.

\subsection{Barriers to equestrian tourism development}

Finally, respondents were asked to rank the top barriers to developing equestrian tourism in their county. The set of barriers is listed below (Table 5) along with the percentages of respondents who ranked each as the first or second largest barrier. Lack of funding for development and Lack of support from officials were the

Table 2

Tourism-related assets present in respondents' home county $\left(n^{1 / 4630}\right)$.

\begin{tabular}{lr}
\hline Tourism-related assets & $\%$ \\
\hline Tack/feed shop & 82.4 \\
Equine practitioner/vet & 79.4 \\
Boarding facilities & 72.9 \\
Riding trails & 68.9 \\
Facility for small-moderate equestrian events (less than 200 participants) & 58.7 \\
Riding lessons available to visitors & 29.0 \\
Farms with horses/ponies that are open to visitors & 28.9 \\
Facility for large equestrian events (serving $200 p$ participants) & 23.0 \\
Lodging that can also board your horse & 20.6 \\
Hack horses/horses to rent for trail rides & 6.2 \\
Other &
\end{tabular}


Table 3

Equine-related assets present in respondents' home county $\left(n^{1 / 4} 631\right)$

\begin{tabular}{lr}
\hline Equine-related assets & $\%$ \\
\hline Farrier services & 89.2 \\
Equine 4-H clubs/pony clubs & 77.3 \\
Livestock or 4-Hshows & 77.2 \\
Organized trail riding groups or saddle clubs & 69.3 \\
County parks, state parks, regional parks or national parks that allow horseback riding & 67.7 \\
Facilities that have hunter-jumper competitions & 56.4 \\
Fairgrounds facility & 55.9 \\
Educational clinics hosted by locals that bring in large name trainers & 48.7 \\
Hunt club & 41.8 \\
Horse themed retail/ gift shop & 41.5 \\
Facilities that host rodeos, western cutting, roping events & 41.0 \\
Pony club horse rallies & 39.5 \\
Horse trials competitions & 37.4 \\
Active presence by equestrian land conservancy groups or trail maintenance groups & 36.6 \\
FFA clubs & 27.1 \\
Horse festivals or places that hold riding demos & 24.4 \\
Steeplechase or similar events & 24.1 \\
Colleges and universities that offer equine programs & 22.7 \\
Parks and recreation equine programming & 18.5 \\
Horseback trail watch/safety group/mounted search and rescue & 13.9 \\
Mounted patrol units or sheriff posse units & 13.9 \\
Horse themed lodging & 11.4 \\
Equestrian law enforcement units within city or county & 10.5 \\
High school equine programs & 8.9 \\
Other & 4.1 \\
\hline
\end{tabular}

Table 4

Trail rider perceptions for equestrian tourism development.

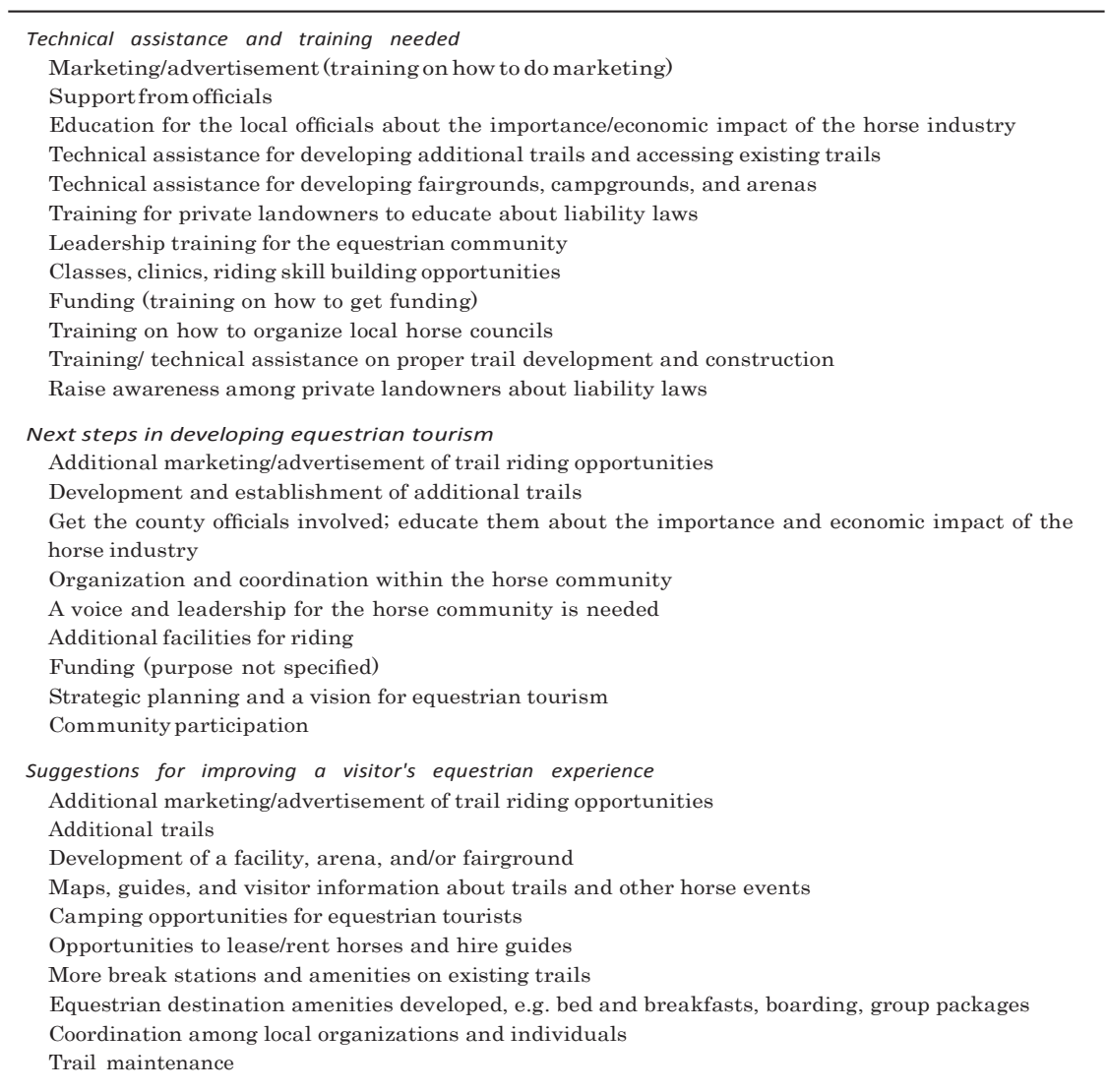

top issues, ranked as the largest or second largest barrier by $43.2 \%$ and $42.5 \%$ of respondents respectively. The response option Low quality/too few equestrian trails received 20.6\%, however was cited repeatedly as a theme throughout the open-ended responses. It is conceivable that the respondents were considering the funding as a necessary predecessor to new trail development when ranking it so high. The sentiments regarding officials' support coincides with sentiments expressed in the open-ended responses. In the open- 
Table 5

Barriers to equestrian tourism development $\left(n^{1 / 4621}\right)$.

Barrier ranked as 1st or 2nd largest barrier $\%$

Lack of funding for development

Lack of support from officials

Lack of organization, vision, managing agency or leadership

Development and urban sprawl/lack of undeveloped land

Low quality/too few equestrian trails

Liability issues

Lack of funding for marketing

Lack of education

Other

ended questions, respondents bemoaned the lack of consideration from county officials and boards, as well as their lack of understanding and undervaluing of the equestrian industry, green infrastructure, and the economic impacts of tourism. The next largest barriers, Lack of organization, vision, managing agency or leadership (29.3\%) and Development and urban sprawl/lack of undeveloped land (28.5\%) are echoed in the open-ended response themes. Survey participants clearly see a need for collaboration between equestrian groups, an organized effort moving forward, and a person or organization taking the lead in this united cause. Trail rider respondents varied in perceived viability for tourism trail development; whereas $15.7 \%$ indicated a low level of viability (1-3), $24.3 \%$ a moderate level (4-6), and $60.1 \%$ a high level of viability (7-10). The second research question explored whether the different ratings of viability are related to the variability in the county's equestrian tourism assets.

\subsection{Variability of ETT viability across county assets}

Analyses were conducted to examine differences in the perception of tourism development viability across county asset characteristics, namely: number of tourism-related assets, number of equine-related assets, and total miles of trails within the county. Viability was determined using the question "Do you think trail riding tourism can be a viable industry for your county? Please respond using a scale of 110, with 1 being not viable at all and 10 being extremely viable." The actual range of responses for this question from survey participants was $1-10$.

To obtain a measure of county assets, the respondents were given a list of 10 tourism-related equestrian assets (see above Table 3), as well as an option to cite other assets available in their county. The total possible number of assets was computed with zero being the lowest number and 11 (if they checked the category of "other") being the highest. The actual range was $0-10$ from survey participants. The same was done using the list of equine-related assets (see above Table 4). The total possible number of equine-related assets numbered 26, including a check for "other." The actual range was 0-21 from survey participants. Using the Pearson product-moment test, these two asset totals were correlated with the question about ETT viability in their county. For both sets of assets, there was a weak but positive correlation: tourism-related assets $\left[r^{1 / 4} .099, n^{1 / 4} 629, p 0.05\right]$ and equine-related assets $\left[r^{1 / 4} .149, n^{1 / 4} 629, p 0.01\right]$.

To account for the potentially perceived arbitrary nature of the 1-10 viability scale, a second analysis was conducted, collapsing the ordinal viability scale into categorical variables of "not viable" (1-3), "moderately viable" (4-6), and "very viable" (7-10). In addition, the tourism-assets scale, and the equine-assets scale were collapsed into similar categories of "low level of assets," "moderate level of assets," and "high level of assets" so that chi-square statistic might be performed to note differences in observed and expected numbers. The tourism-related assets variable did not yield significant differences on perceptions of ETT viability. Respondents with a low and moderate level of equine-related assets, however, $X^{2}\left(4, n^{1 / 4} 629\right) 1 / 4$ $12.842, p^{1 / 4} .012$, were more likely to think that ETT was viable compared to respondents with a high level of equine-related assets $\left(M^{1 / 4}\right.$ 7.32).

Finally, the relationship between miles of trails in the county and perceived ETT viability was examined. The number of miles were approximated by the question, How many miles of riding trails would you estimate are in your county?, where respondents selected from categories of mile ranges in 50-mile increments ( 050 miles, 50-100 miles, etc.). The two categories with the highest number of trails, 150-200 miles and 4200 miles, were collapsed to create similarly sized groups. A chi-square analysis was used to note differences in observed and expected numbers. The test was found to be significant, with respondents feeling generally pessimistic about the viability of ETT in their county, $X^{2}\left(8, n^{1 / 4} 584\right)^{1 / 4} 16.470, p^{1 / 4} .036$. Respondents with 50-100 estimated miles of trails were the most optimistic about ETT, and respondents with more than 150 estimated miles of trails were moderately optimistic about ETT more than expected. The third question explored whether the different ratings of viability are related to individual characteristics of the respondents.

\subsection{Variability of ETT viability across respondents}

To examine differences in the perception of tourism development viability across individual characteristics, specifically age, employment and rider-experience, additional analyses were conducted. In light of the fact that almost all of the respondents (88\%) were women, an analysis of gender differences was not performed. The independent variables of age, employment and rider-experience are all categorical. In order to have similarly sized groups, some categories were collapsed, and others, with very low numbers of respondents, were dropped. Age was collapsed into Younger (up to 49 years old, $n^{1 / 4} 236$ ) and Older (50 years old or above, $n^{1 / 4} 268$ ) to generate similar sized groups. Public and non-profit employees were collapsed, as were private sector and self-employed categories, to make two similar sized groups, Public/non-profit employed ( $\left.n^{1 / 4} 215\right)$ and Private/self-employed $\left(n^{1 / 4} 269\right)$. Responses in the categories of student $\left(n^{1 / 4} 10\right)$, retired $\left(n^{1 / 4} 97\right)$, unemployed $\left(n^{1 / 4} 19\right)$, and other $\left(n^{1 / 4} 18\right)$ were dropped to maintain similar-sized groups. Within the self-categorized rider-experience variable, the competitive $\left(n^{1 / 4} 60\right)$ and novice categories $\left(n^{1 / 4} 22\right)$ were dropped due to their low numbers, leaving the Avid Trail Riders $\left(n^{1 / 4} 352\right)$ and Occasional Trail Riders ( $\left.n^{1 / 4} 192\right)$.

There were no significant differences found between employment and riding level variables, therefore employment sector and rider experience did not influence the respondent's perception of ETT viability. Age however, did have an effect. Using the viability scale in both its continuous and categorical forms, $t$-test revealed significant mean differences, $t(502) 1 / 4-3.548$, po.001. Eta squared was .024 , which is classified as a small effect (Pallant, 2005). When the viability variable was collapsed into "not viable" (1-3), "moderately viable" (4-6), and "very viable" (7-10) categories and the chi-square test was applied, the results were also found to be significant, with the younger respondents feeling more optimistic than expected about the viability of ETT in their county, and the older respondents more pessimistic, $\mathrm{X}^{2}\left(2, n^{1 / 4} 504\right)^{1 / 4} 9.723, p^{1 / 4} .008$.

\section{Discussion}

Trails are a valued form of outdoor recreation appealing to many different types of users. A variety of uses are supported by trails: hiking, horseback riding, biking, skiing, snowmobiling, snowshoeing, cross country skiing, walking, jogging, and others (American Trails, 2011). A challenge for managers and planners is designing and maintaining trails that appeal to diverse groups of users. While a great deal of research has been completed to evaluate the value of trail use, 
horse trails have not been a primary focus. In addition, the perspective of resource users (i.e., horse trail riders) from the communities where trails exist has not been sufficiently explored. Understanding the amount of use, the kinds of use, the sorts of people who participate, and attitudes about horse trails from the viewpoint of resource users are essential for thoughtful planning, development, and management.

The current study attempted to understand interest in, and potential for, developing horse trails in a southeastern community in the U.S. While there are many stakeholder groups involved in tourism development, the current study focused the resource users, horse trail riders. Who better to identify the viability and requirements for successful equestrian tourism development than members of the horse trial rider community? The study sought to understand the perceptions and attitudes of horse trail riders to gain insight and information allowing rural tourism planners, and those interested in ETT, to successfully develop ETT and effectively meet the needs of the horse trail rider community.

According to horse trail riders, sufficient assets currently exist in the community to meet the needs of increased tourism growth and continued expansion of horse trail tourist market. Results suggest that the majority $(60.1 \%)$ of respondents viewed ETT as a viable industry for their county. However, few (13.8\%) indicated knowledge of tourists whose travel purpose was horse trail riding. These results show great support and potential for expanding market share. Respondents indicated that existing infrastructure is available (e.g., tack/feed shop, equine practitioner/vet, boarding facilities, and riding trails) to meet the needs of tourists interested in ETT. However, the results suggest the need to build awareness of ETT in many of the respondents' home counties. More specifically, lack of awareness among various stakeholders beyond the trail riding community (e.g., government, business, and landowners) needs to be expanded in order to see efforts related to ETT development come to fruition.

The results of this study are salient to community-based tourism development which is organized around the themes of collaboration within the horse community, education and awareness, planning and product development, and marketing. These themes are described in the paragraphs below, followed by the proposed Community Tourism Development Planning Model based on the findings of this study and revised for ETT projects.

\subsection{Collaboration within the horse community}

The first step in successfully developing equestrian tourism is collaboration within the horse community. As suggested by the results, there is a clear need for organization and mobilization among the horse community. In order to communicate beyond their own boundaries, the horse community needs to have a common voice regarding the benefits of equestrian tourism. Previous research in tourism development indicates that level of support for tourism increases when key stakeholders understand the perceived benefits and costs (Jurowski, Uysal, \& Williams, 1997; Perdue, Long, \& Allen, 1990; Snaith \& Haley, 1995). To achieve goals the horse community needs to work together to identify a strategic plan for development marketing. Partnerships are essential in building community. Thus, incorporating feedback from beyond the horse community is essential.

\subsection{Education and awareness}

Similar to the technical report regarding equestrian tourism development produced in North Carolina, respondents in the current study ranked education and awareness as the highest among priorities necessary for development (Kline et al., 2006). Clearly, existing trail riders feel that the local officials do not appreciate the value of open space, recreational trails, the horse industry or tourism. Additional audiences identified education and training as priorities including: landowners; existing and potential riders, the local business community, and the general public. Salient topics suggested to be the focus of education programs were: liability issues; the value of equestrian tourism; technical assistance on how to develop equestrian tourism for specific to existing and potential riders, techniques to hone skills and increase future enjoyment of the activity.

\subsection{Planning and development of product}

Generally, respondents from the survey tend to support tourism largely as a community development strategy. However, careful planning, design, development, maintenance and management are essential. Researchers have proposed a variety of benefits associated with open space including personal, social, environmental, and economic (McConnell \& Wall, 2005). In addition, desire for parks and open space is growing underlining the need for planning for open space and reducing sprawl.

The size and distribution of a horse's weight makes horse riding more damaging to the surrounding environment than other recreational activities such as hiking (Landsberg et al., 2001; Pickering, Hill, Newsome, \& Leung, 2010). However, sustainable trail management can be achieved by good planning. According to Marion and Leung (2004), trails designed specifically for particular users and taking the physical characteristics of the land into consideration will suffer fewer impacts and will be more sustainable than a poorly designed trail. In addition, facilities should be designed with the users in mind. Respondents indicated that facilities should be developed to meet the needs of the users by providing a visitor-friendly experience that includes amenities, signage with distance and grade markings, and sufficient parking that will facilitate horse trailers.

\subsection{Marketing}

To promote ETT, the relationships among tourism, local people, and biodiversity conservation in the study area must be strengthened. According to the findings, some suggestions are to foster better relationships. Areas suggested for improvement within the realm of marketing included improved visitor information, including maps and guides. In addition, a number of partnerships would enhance the overall visitor experience by linking together the existing tourism infrastructure (accommodations and other tourism-related businesses and activities) with horse-related businesses and infrastructure. Finally, consumer data needs to be collected to better understand the consumer patterns of equine tourist. Very little is known with respect to spending patterns, and their overall consumer behavior.

\subsection{Tourism development planning model for ETT}

The Community Tourism Development Model (Reid et al., 1993) was used as the basis for the analysis of this study's results. The results of this study provide partial support for Reid's model, but also highlight gaps in the model when applied to the development of a specific type of community-based tourism asset, such as ETT. Similarities among these findings and the model involve education and awareness, product development, and marketing. Each of these three areas were mentioned by survey participants as important to equestrian trail development.

The findings from this study deviate from what is expected in the model in two ways. The first deviation involves the organizational structure, which is in the model but not in the findings. The second deviation involves collaboration within the community, which is in the findings but not in the model.

A niche recreation and tourism activity, such as equine trail riding in a state like Virginia, may not have formalized organizational structures in most communities. Although the Virginia Horse Council is a statewide organization, the development of trail riding areas is typically left up to local communities, as confirmed by the data. According 


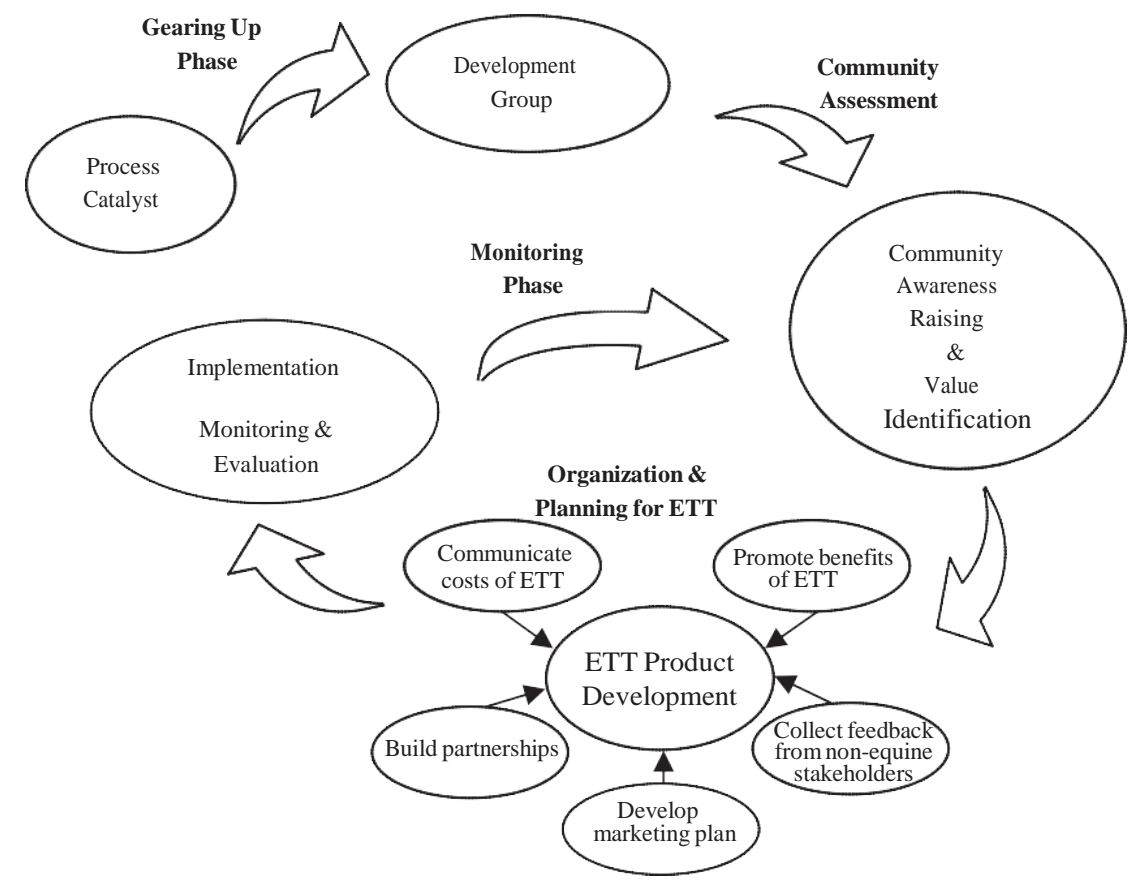

Fig. 2. Community Tourism Development Planning Model for Equestrian Trail Tourism.

to this research, the formal organizational structure is replaced by a looser collaboration within the horse community when it comes to product development and marketing. The less formal collaboration creates different needs and influences as development progresses through the "Organization \& Planning Phase" of the CommunityBased Tourism Development model. Those needs are: 1) promoting the benefits of equestrian tourism, 2) communicating the costs of equestrian tourism, 3) develop a strategic marketing plan, 4) build partnerships, and 5) collect feedback from non-equine stakeholders. Based on the findings and analysis from this study a revised community tourism development model is proposed. Equine tourism development may look more like the figure provided below (Fig. 2). In addition, this model can be applied to other types of tourism development that are being pursued by informal community groups.

This research reiterates the findings of Reid et al. (2004) and shows how a community with a development group, such as the Virginia Horse Council, can respond to a catalyst - escalating demand for niche tourism alternatives, in this case - and can assess the community to identify new tourism development opportunities. This research extends the model to show what is necessary to develop more specific forms of alternative tourism, such as equestrian trail tourism.

\section{Conclusions}

The current study examined a growing niche of the tourism industry, equestrian tourism. Increasing demand for special interest tourism makes careful development and planning critical. Stakeholder involvement is important in any tourism development scenario, however this study focused on gaining insight from a specific stakeholder group, resource users. The purpose of the study was to understand the perceptions and attitudes of trail riders related to ETT development in their community. The findings suggest that sufficient assets exist to support a focus on expanding horse trail tourist market within Virginia. Not only was ETT viewed as a viable industry for the county, current resource users voiced their support for expanding the market, which would result in retention and growth of the existing horse trail related businesses and facilities. The primary issue that needs to be addressed is the lack of awareness beyond the trail riding community about the economic benefits of such development. Results of the study will assist rural tourism planners wishing to increase ETT. The overall findings suggest that great partnerships are essential in building community and successfully developing horse trails that meet the needs of the riders while limiting conflict between multiple user groups.

\subsection{Implications for researchers, managers and policymakers}

A number of practical implications emerged from the results of the study. By engaging with community stakeholders including elected officials, landowners, and regional tourism marketers, the horse community could make great strides in the development of new horse trails and facilities, maintenance of existing ones, marketing of horse trail experiences, and in an overall greater appreciation of the equine industry and its relationship to land conservation and stewardship.

Future studies on equestrian tourism development could compare the responses of trail riders within the community with other stakeholders. Although research such as that presented here can provide useful information to tourism development agencies, additional insights can be gained using quantitative methods to measure many of the issues referenced here: support from local officials, funding, organization and collaboration within the horse community, leadership and voice of the horse community, product development/management, protection of open space, packaging, marketing, consumer behavior, understanding of liability issues, community and business support, and nurturing current and future equestrian markets.

\section{Acknowledgments}

We would like to acknowledge the Virginia Horse Council, and especially Sally Aungier, for their assistance in the implementation of the 2008 Virginia Equestrian Trail Rider Survey. 


\section{References}

American Horse Council (n.d). National impact of the U.S. horse industry. Retrieved August 4th, 2011 from $\langle\mathrm{http}: / / \mathrm{ww}$ w.horsecouncil.org/nationaleconomics.php $\rangle$ American Trails. (2011). Retrieved September 23, 2011 from 〈http://americantrails. $\operatorname{org} /\rangle$.

Beeton, S. (1999a). Hoof prints on the mind: exploration of altitudinal relationships between bushwalkers and commercial horseback tours. Tourism Management, $20(2), 255-259$

Beeton, S. (1999b). Hoofing it - on four or two feet? Managing multi-use trails and sites. Current Issues in Tourism, $2(2$ and 3), 211-225.

Beeton, S. (2001). Horseback tourism in Victoria, Australia: cooperative, proactive crisis management. Current Issues in Tourism, 4(5), 422-439.

Biches-Lupas, M., \& Moisey, N. R. (2001). A benefit segmentation of rail-trail users: implications for marketing by local communities. Journal of Parks \& Recreation Administration, 19(3), 78-92.

Blood-Horse Magazine. (2013). Kentucky equine survey releases findings. Retrieved on May 1, 2013 from 〈http://www.bloodhorse.com/horse-racing/articles/75759/ kentucky-equine-survey-releases-findingsixzz2So99DguV $\rangle$.

Boers, B., \& Cottrell, S. (2007). Sustainable tourism infrastructure planning: a GIS supported approach. Tourism Geographies, 9(1), 1-21.

Byrd, E. T. (2007). Stakeholders in sustainable tourism development and their roles: applying stakeholder theory to sustainable tourism development. Tourism Review, 62(2), 6-13.

Byrd, E. T., Cardenas, D.A, \& Greenwood, J. B. (2008). Factors of stakeholder understanding of tourism: the case of Eastern North Carolina. Tourism and Hospitality Research, 8, 192-204.

Daniels, M. J., \& Norman, W. C. (2005). Motivations of equestrian tourist: an analysis of the colonial cup races. Journal of Sport Tourism, 10(3), 201-210.

Deluca, T. H., Patterson, W. A., IV, Freimund, W. A., \& Cole, D. N. (1998). Influence of llamas, horse, and hikers on soil erosion from established recreation trails in western Montana, USA. Environmental Management, 22(2), 255-262.

Donaldson, T., \& Preston, L. E. (1995). The stakeholder theory of the corporation: concepts evidence, and implications. The Academy of Management Review, 20 (1), 65-91.

Freeman, R. E. (1984). Strategic management: a stakeholder approach. Boston: Pitman.

Goeldner, C. R., \& Ritchie, J. B. (2012). Tourism: principles, practices, philosophies (12th ed.). Hoboken, NJ: John Wiley \& Son.

Gray, B. (1989). Collaborating: finding common ground for multiparty problems. San Francisco: Jossey-Bass.

Hackbert, P., \& Lin, X. (2009). Equestrian trail riding: an emerging economic contributor to the local rural Appalachian economy. Journal of Business Case Studies, 5(6), 47.

Helgadóttir, G. (2006). The culture of horsemanship and horse-based tourism in Iceland. Current Issues in Tourism, 9(6), 535-548.

Helgadottir, G., \& Sigurdardottir, I. (2008). Horse-based tourism: community, quality and disinterest in economic value. Scandinavian Journal of Hospitality and Tourism, 8(2), 105-121.

Ivy, M. I., \& Moore, R. L. (2007). Neighboring landowner attitudes regarding a proposed greenway trail: assessing differences between adjacent and nearby residents. Journal of Park and Recreation Administration, 25(2), 42-63.

Jamal, T. B., \& Getz, D. (1995). Collaboration theory and community tourism planning. Annals of Tourism Research, 22(1), 186-204.

Jurowski, C., Uysal, M., \& Williams, R. D. (1997). A theoretical analysis of hos community resident reactions to tourism. Iournal of Travel Research, 36(2), 3-11.

Kline, C., Cardenas, D., Duffy, L, \& Swanson, J. (2012). Funding sustainable paddle trail development: paddler perspective, willingness to pay and management implications. Journal of Sustainable Tourism, 20(2), 235-256.

Kline, C., Potter, T., \& Mowrey, R. (2006). Developing equine tourism opportunitie in North Carolina: an online survey of county needs. Technical report, Retrieved October 2, 2012 from 〈http://www.ncsu.edu/tourismextension/programs/projects.php $\rangle$.

Kyle, G., Graefe, A., \& Manning, R. (2004). Attached recreationists. Who are they? Journal of Parks and Recreation Administration, 22(2), 65-84.

Landsberg, J., Logan, D., \& Shorthouse, D. (2001). Horse riding in urban conservation areas: reviewing scientific evidence to guide management. Ecological Management and Restoration, 2(1) 36-46.

Marion, J.L., Cole, D.N., \& Bratton, S.P. (1986). Exotic vegetation in wilderness areas. In Proceedings of the National Wilderness Conference, Current Research (pp. 114-119).
Fort Collins, Colorado: USDA, Forest Services, Intermountain Research Station, General Technical report, INT-122.

Marion, J. L., \& Leung, Y. F. (2004). Environmentally sustainable trail management. Environmental impact of tourism, 229-244.

Marion, J., \& Leung, Y. (2001). Trail resource impacts and examinations of alternative assessment techniques. Journal of Parks and Recreation Administration, 19(3), 17-37.

Marion, J. L., Roggenbuck, J. W., \& Manning, R. E. (1993). Problems and practices in backcountry recreation management: a survey of national park service managers. Washington, DC: U.S. Dept. of the Interior, National Park Service, Natural Resources Publication Office.

McConnell, V., \& Wall, M. (2005). The value of open space: evidence from studies of non-market benefits. Washington, DC: Resources for the Future.

Moore, R. L., \& Shafer, C. S. (2001). Introduction to special issue trails and greenways: opportunities for planners, managers, and scholars. Journal of Park, Recreation Administration, 19(3), 1-16.

Mulders, C. (2006). Western Australian equestrian tracks and trails study [PowerPoint presentation]. Retrieved August 5th 2011 from 〈http://www.svpa.com.au/ index_files/Equestrian_tracks_and_trails_presentation.pdf $\rangle$.

Newsome, D., \& Davies, C. (2009). A case study in estimating the area of informal trail development and associated impacted caused by mountain bike activity in John Forrest National Park, western Australia. Journal of Ecotourism, 8(3), 237253.

Newsome, D., Milewski, A., Phillips, N., \& Annear, R. (2002). Effects of horse riding on national parks and other natural ecosystems in Australia: implications for management. Journal of Ecotourism, 1(1), 52-74.

Newsome, D., Smith, A., \& Moore, S. A. (2008). Horse riding in protected areas: a critical review and implications for research and management. Current Issues in Tourism, 11(2), 144-166.

N.C. Center for Rural Economic Development (2009). North Carolina equine industry. Retrieved August 17th, 〈http://www.ncruralcenter.org/images/PDFs/ Publications/equinestudy050809.pdf $\rangle$.

Perdue, R. R., Long, P. T., \& Allen, L. A. (1990). Residents support for tourism development. Annals of Tourism Research, 17(4), 586-599.

Räbinä, R. L. (2010). Benchmarking Finnish and Irish equestrian tourism. Finland: School of Tourism, Kajaani University of Applied Sciences (Unpublished thesis).

Royce, P. (1983). Horse riding trails in John Forrest National Park: an environmental impact assessment. Perth, W.A., Australia: National Parks Authority of Western Australia.

Oh, C., \& Hammitt, W. (2010). Determining economic benefits of park trails: management implications. Journal of Park and Recreation Administration, 28 (2), 94-107.

Ollenburg, C. (2005). Worldwide structure of the equestrian tourism sector. Journal of Ecotourism, 4(1), 47-55.

Pallant, J. (2005). SPSS survival manual. Columbus, OH: McGraw-Hill International.

Phillips, N., \& Newsome, D. (2002). Understanding the impacts of recreation in Australian protected area: quantifying damage caused by horse riding in D'Entrcasteaux National Park Western Australia. Pacific Conservation Biology, 7, 256-273.

Pickering, C. M., Hill, W., Newsome, D., \& Leung, Y. (2010). Comparing hiking, mountain biking and horse riding impacts on vegetation and soils in Australia and the United States of American. Journal of Environmental Management, 91, 551-562

Reid, D., Fuller, A., Haywood, K., \& Bryden, J. (1993). The integration of tourism, culture and recreation in rural Ontario: a rural visitation program. Toronto: Queen's Printer, The Ontario Ministry of Culture Tourism and Recreation.

Reid, D., Mair, H., \& George, W. (2004). Community tourism planning: a selfassessment instrument. Annals of Tourism Research, 31(3), 623-639.

Reid, D., Mair, H., \& Taylor, J. (2000). Community participation in rural tourism development. World Leisure, 42(20), 20-27.

Snaith, T, \& Haley, A. (1995). Tourism's impacts on host lifestyle realities. In: A V. Seaton, C. L. Jenkins, R. C. Wood, P. U.C. Dicke, M. M. Bennett, L. R. MacLellan, $\&$ R. Smith (Eds.), Tourism: The State of Art (pp. 826-835). New York: John Wiley \& Sons.

Törn, A., Tolvanen, A., Norokorpi, Y., Tervo, R., \& Siikamäki, P. (2009). Comparing the impacts of hiking, skiing and horse riding on trail and vegetation in different types of forest. Journal of Environmental Management, 90(3), 1427-1434.

Watson, A. E., Niccolucci, M. J., \& Williams, D. R. (1994). The nature of conflict between hikers and recreational stoke uses in the John Muir Wilderness. Journal of Leisure Research, 26(4), 372-385. 